\title{
The Effect of Digitalization on the Commercialization Process of High-Technology Companies in the Life Sciences Industry
}

\author{
Saheed A. Gbadegeshin
}

\author{
" Digital transformation is a long journey, and the" \\ path for digital transformation can be iterative, \\ evolutionary, revolutionary, or disruptive. \\ Pearl Zhu \\ Author of Digital Maturity
}

\begin{abstract}
This article examines how digitalization influences the commercialization of high technologies in the life sciences industry. It is based on a cross-case study focused on pharmaceutical, medical device, and e-health companies in Finland. Both company representatives and regional stakeholders were interviewed. The findings suggest that "digitalization" needs to be distinguished from "digitization" because both terms seem to be misused or used interchangeably. The findings also show that digitalization led to a concurrent implementation of commercialization processes. Furthermore, the findings revealed that digitalization positively influenced commercialization activities, especially information sourcing and management, various assessments, and official activities, big data creation, and activity routinization. It was also revealed that the creation of new sets of big data and fear of digital attacks are negative influences on digitalization. These findings make a theoretical contribution to the discourses on digitalization and commercialization, but they also provide insights for scientists, engineers, and life science companies.
\end{abstract}

\section{Introduction}

Digitalization is influencing almost every sphere of human activity. Indeed, digitalization has come to stay as the Fourth Industrial Revolution keeps evolving and impacting our lives in countless ways (Parviainen et al., 2017; Tihinen \& Kääriäinen, 2016). It influences communication patterns, working styles, transportation systems, and even manufacturing processes (Schwab, 2015; The Economist, 2012). It fuses many technologies and, thereby, it blurs the lines between different facets of everyday life. For example, physical products, digital services, and biological spheres are now intertwined (Gerlitz, 2015). This situation is changing every sphere of business operations and society's activities as a whole (Degryse, 2016).

However, despite the widespread impact of digitalization, scholarly studies on the subject are not yet common. Many of the writings that do exist are written by practitioners in form of reports, whitepapers, consulting firm service guides, and blogs. These articles centered on digital transformation and they are opinion-based (Parviainen et al., 2017). Few articles coming from academia have only focused on digital technologies, and their business model, business operation, and users' experience (Henriette et al., 2015).

With respect to the limited number of scholarly studies on digitalization, this article aims to reduce the gap and to provide more knowledge about how it affects the commercialization process of high technologies in the life sciences industry. This industry is well known for its strict regulations, its expensive research and development $(\mathrm{R} \& \mathrm{D})$, and its unique and complex development process (Kaitin, 2010; Khilji et al., 2006; Maak \& Wylie, 2016; McKenzie et al., 2006). Within this industry, three sectors were the focus of the current study: the pharmaceutical sector (specifically, new drug development), the medical device sector, and the e-health sector. 


\section{The Effect of Digitalization on the Commercialization Process of High-Technology Companies in the Life Sciences Industry Saheed A. Gbadegeshin}

These sectors were selected because their technologies are complex, highly innovative, $R \& D$ dependent, and resource intensive (Eurostat, 2016; Steenhuis \& de Bruijn, 2006). These features represent characteristics of high technologies (Solberg et al., 2008). Therefore, exploring digitalization and its influences on the commercialization process of the industry would provide in-depth knowledge, which is essential for the development of commercialization skills (Gbadegeshin, 2019). Thus, the following research question was explored:

\section{How does digitalization influence the commercial- ization process of high-technology companies in the life sciences industry?}

To answer this question, the article employed a qualitative research method through a cross-case study analysis. Stakeholders of the industry, which consisted of entrepreneurs, business advisors, government officers, and university technology transfer officers (UTTOs) were interviewed, and the resulting data were analyzed with a thematic method.

The rest of the article is structured as follows: literature overview, methodology, findings and discussion, and conclusion. The literature overview section discusses digitalization and commercialization processes in the life sciences industry. Next, the methodology section describes the interview and data analysis procedures. The findings and discussion section explains the results of the article and their relationship with previous studies. The final section outlines the study's contribution and areas for further research.

\section{Literature Overview}

\section{Digitalization}

"Digitalization" is often interchangeably used with "digitization". Both concepts are related, but they denote different things. Digitalization is an organization of several and diverse social life spheres via digital communication technologies, whereas digitization is a conversion of analogue information into digital forms. Scholarly, digitalization is a structuring of those technologies across: infrastructural, terminal, functional and rhetorical, and market convergence dimensions (Brennen \& Kreiss, 2016), process, organization, business domain (Parviainen et al., 2017), industries (Tihinen \& Kääriäinen, 2016), and the entire economy and society levels (Degryse, 2016; Parviainen et al., 2017). Deductively, in this article, digitalization refers to the use of any digitalization technology on any part of commercialization activities of companies.
Furthermore, digitalization technologies consist of artificial intelligence (AI), robots, automation, Internet of Things, big data, 3D printing, autonomous vehicles, drones, cyber-weapons, surveillance (Brennen \& Kreiss, 2016; Degryse, 2016: 19; Schwab, 2015), nanotechnology, biotechnology, material science, energy storage, and quantum computing (Manyika et al., 2013; The Economist, 2012). Others are: blockchain, smart cities, brain-inspired computing, social computing, cloud computing, smart grids, digital circuits, factory automation, fuzzy logic, expert systems, agents and multi-agent systems, natural language processing, data mining, sentiment analysis, human-computer interaction, image processing, geographic information systems, video analysis, medical diagnosis, segmentation techniques, augmented reality, virtual reality, satellite communication systems, 5G network evolutions, biometrics, electronic data interchange, cryptocurrencies, e-learning, e-business, digital marketing, and virtual organizations (Gbadegeshin, 2019).

The primary motives for the use of digitalization by industries are to reduce cost (Manyika et al., 2013), enhance performance (Markovitch \& Willmott, 2014), promote internal efficiency (Parviainen et al., 2017), improve smart production process (Gerlitz, 2015), add value to a supply chain (Tihinen \& Kääriäinen, 2016), create a new product or service (Degryse, 2016), adapt to new changes (Henriette et al., 2015), manage competition, and stimulate demand (Sabbagh et al., 2012). Parviainen and colleagues (2017) explain that:

"The potential benefits of digitalization for internal efficiency include improved business process efficiency, quality, and consistency via eliminating manual steps and gaining better accuracy. Digitalization can also enable a better real time view on operation and results, by integrating structured and unstructured data, providing better views on organization data, and integrating data from other sources. Furthermore, digitalization can lead to better work satisfaction for employees through automation of routine work, thus freeing time to develop new skills. Digitalization also improves compliance via standardization of records and improves recovery via easier backups and distribution of storage."

Digitalization has been employed in the life sciences industry since the introduction of process analytical technology (which was proposed by the Food and Drug Administration of the United States). The Process analytical technology entails online measurements, 


\section{The Effect of Digitalization on the Commercialization Process of High-Technology Companies in the Life Sciences Industry Saheed A. Gbadegeshin}

real-time control, risk analysis, application of statistical and multivariate analyses, laboratory automation, miniaturization, design of experiments, and use of physical organic chemistry (McKenzie et al., 2006). An example is the use of a high-throughput screening (HTS) tool. This tool plays significant roles in miniaturization, automation, and parallelization of pharmaceutical processes (Bhambure et al., 2011). In fact, Bhambure and colleagues (2011) conclude that: "We are confident that this will occur over the next decade and that the widespread of HTS tools and approaches will dramatically change how we perform the various activities that are required for product and process development and commercialization."

The situation is fast approaching, as it is shown in the pharmaceutical landscape that, by 2025, there will be an intervention treatment instead of current prevention treatment. This need would serve as a driver and it would compel the sector to improve its commercialization (Tierney et al., 2013). Thus, most major players in the sector are changing their present $R \& D$ practices (Kaitin, 2010). Therefore, it is important to understand the application of digitalization on the commercialization activities, for example, through the current study.

\section{The commercialization process in the life sciences} industry

The commercialization process consists of several activities for transforming new innovations into products or services (Fontes, 2005; Meyers, 2009; Speser, 2008). It is a way of bringing new technologies to the market (Pellikka \& Malinen, 2011) so that returns can be made on $\mathrm{R} \& D$ investments (Cornford, 2002) or to make the technologies beneficial for society (Nissen et al., 2015). To achieve these returns and benefits, there must be an efficient channel and a cost-effective means to transfer the innovations from research institutes to commercial-oriented organizations (Nilsson et al., 2006). The efficient channel refers to appropriate commercialization methods (Gbadegeshin, 2017a), which depends on the sector's process. The typical commercialization process in the life sciences industry is complex, long, and unique (Khilji et al., 2006). Thus, scholars have developed different frameworks, for example, a stage-gate model, to facilitate the process (Soenksen \& Yazdi, 2017). Because this study is focused on new drug development, medical devices, and e-health companies, their commercialization processes are briefly explained below.

First, the commercialization process of new drug development is typically grouped into three phases: 1) prelaunch, 2) marketing and sales, and 3) post-exclusivity.
In the phase, pre-launch, $R \& D$, clinical tests, and clinical trials are conducted. In the second phase, marketing and sales, new products are sold. A sale usually involves the transfer of exclusive intellectual property (IP) to a large pharmaceutical company. The last phase, post-exclusivity, occurs when the new product is widely available to the populace and can be copied by competitors (European Commission, 2009). However, this is not the only way to envision the commercialization process in the life sciences industry. The process also can be divided into three phases that correspond to discovery, pre-clinical testing, and post-discovery. Alternatively, these phases can be described as five stages: 1) basic research, 2) innovation and invention, 3) early-stage technology development, 4) product development, and 5) production and marketing (Khilji et al., 2006). Furthermore, Sternitzke (2010) identifies only two phases in the commercialization process: 1) early research and preclinical and 2) clinical. Additionally, Dogra and colleagues (2013) group the process into four phases, but they further break down the process into sub-phases. For example, the sub-phases of discovery are research target, biological evaluation, integrated research, candidacy, drug formation, and patent filing. All these various models show that the commercialization process may be conceptualized with different phases and different names, but there are similarities, especially when it comes to discovery and clinical tests. In Figure 1, the various models described above are combined into a generalized new drug development commercialization process that has six main stages.

Second, consider the commercialization process for medical devices. Despite the diversity of devices, many producers employ a stage-gate model. The process typically consists of five stages: 1) initiation, 2) formulation, 3) design and development, 4) final validation, and 5) product launch and post-launch evaluation (Pietzsch et al., 2009). Similarly, the process can be grouped into discovery, incubation, and acceleration (Holzleitner, 2015), or into discovery and identification of technological opportunity, exploitation of commercial opportunity, and development of the technological product (Abd Rahim et al., 2015). More comprehensively, the process can be broken down into nine steps: 1) basic and applied science, 2) application idea, initial technical, and economic viability, 3) scanning and creation of potential alliances, 4) identification of specific need of target market, 5) customization of R\&D - designing and prototyping, 6) customer testing and experimentation, 7) verification of relating policies, 8) development of a pilot plant, and 9) final customer testing. These steps have three tiers, which include basic research, broad application of basic 


\section{The Effect of Digitalization on the Commercialization Process of High-Technology Companies in the Life Sciences Industry Saheed A. Gbadegeshin}

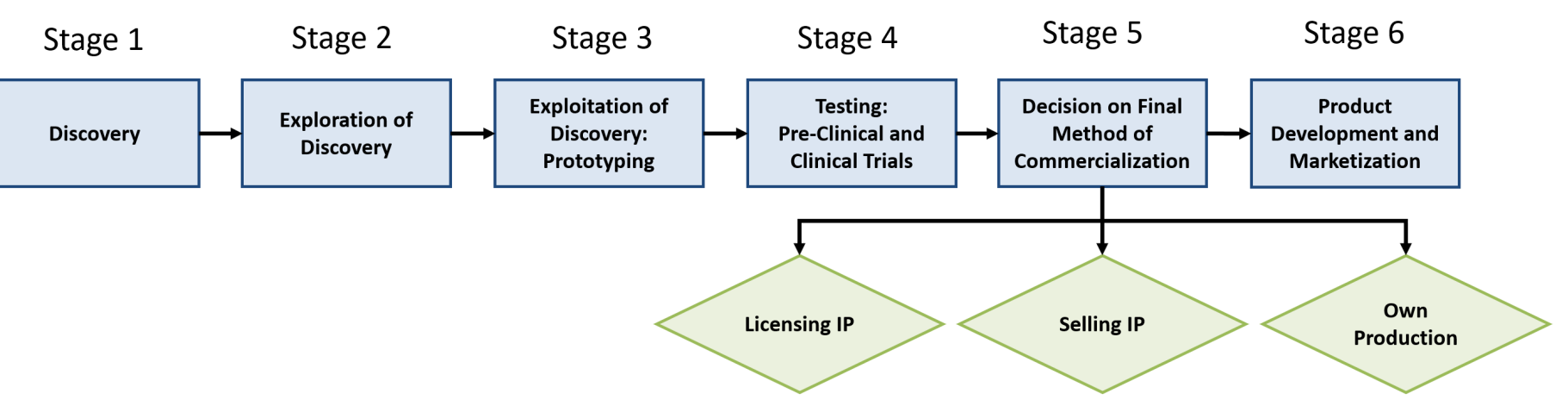

Figure 1. A generalized new drug development (pharmaceutical) commercialization process

research, and identification of specific application (Maine and Garnsey, 2007). Taken together, these various models can be generalized into the process shown in Figure 2.

Third, e-health is described as the use of information and communication technology (ICT) to link and educate healthcare stakeholders (such as governments, healthcare providers, and patients). It is the use of ICT to promote delivery of high-quality services in a healthcare system. It also includes the promotion of efficiency and effectiveness of healthcare system management (World Health Organization, 2003). E-health has an impact on patients' lives, especially those who need intensive healthcare services, such as the elderly or people with disabilities or chronic illnesses (Kumar et al., 2013; Silva et al., 2015). Other terms use synonymously with (or as subcategories of) e-health are mhealth (Kumar et al., 2013; Istepanaian \& Zhang, 2012), telehealth (Cho et al., 2008), telematics (Silva et al., 2015), and telemedicine (Silva et al., 2015). E-health consists of medical applications, wearable sensors, mobile devices, and health records (Silva et al., 2015). Despite the importance of e-health, there are few studies on how e-health innovations move from their origins to sustainable market acceptability. Academic work discussing the migration of an e-health idea to the marketplace is rare (Cho et al., 2008). Moreover, many initiatives and projects on e-health fail due to improper or insufficient analyses of business models (Mettlera \& Eurich, 2012; Cho et al., 2008). To address e-health challenges, Cho and colleagues (2008) present a framework that shows four stages in the commercialization process of e-health: 1) adoption, 2) implementation, 3) commercialization, and 4) diffusion. It is shown in Figure 3.

Considering all the above processes, it can be noted that they imply a stage-gate model. This assertion seems to be common for technology commercialization in which an invention or innovation comes from a research institute (e.g., a university) (Al Natsheh et al., 2013; Bradley et al. 2013). However, following the stages in a strict and orderly fashion may not necessary (Al Natsheh et al., 2014; Gbadegeshin, 2017b), because simultaneous development of product and market is an essential step in the commercialization process nowadays. For example, developing a product and its market simultaneously is common in the commercialization of medical devices such as microfluidic devices (Volpatti \& Yetisen, 2014) and e-health applications (Mettlera \& Eurich, 2012).

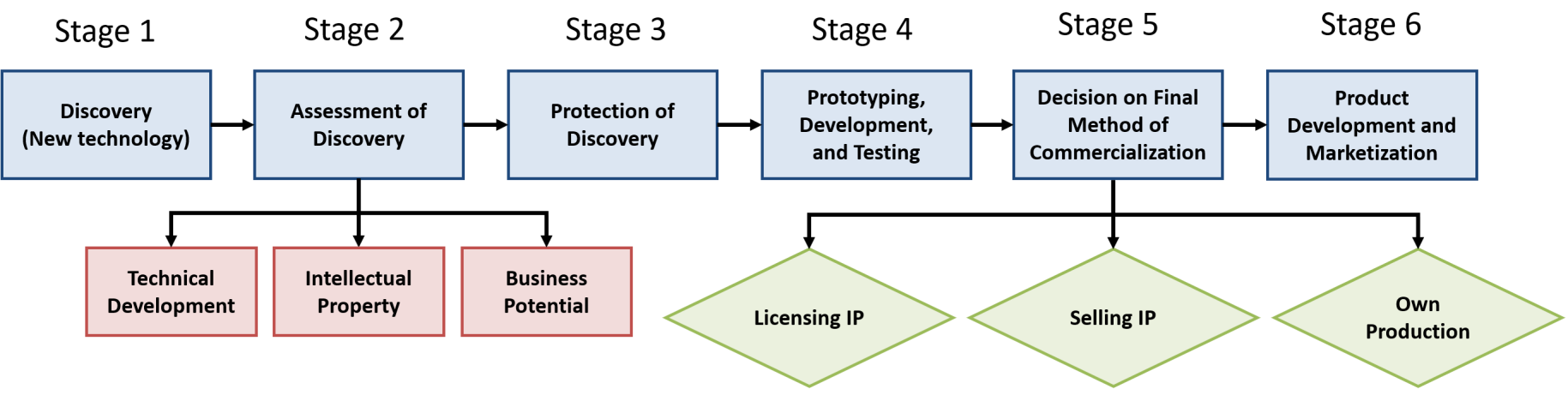

Figure 2. A generalized medical device commercialization process 


\section{The Effect of Digitalization on the Commercialization Process of High-Technology Companies in the Life Sciences Industry Saheed A. Gbadegeshin}

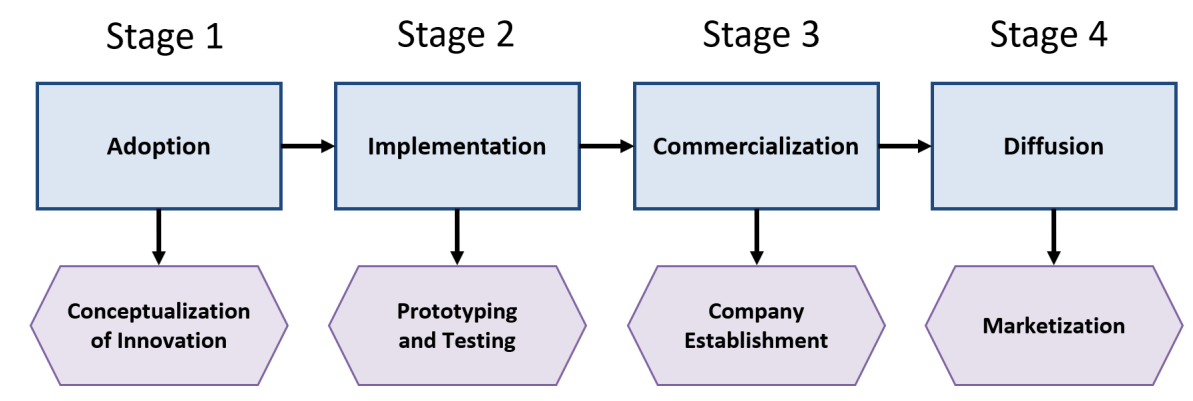

Figure 3. The e-health commercialization process (Adapted from Cho et al., 2008)

\section{Methodology}

A case study method is recommended to be used in order to facilitate mutual understanding of the commercialization process (Gaubinger et al., 2012; Pellika, 2014; Prebble et al., 2008; Siegel et al., 2004; Walsh, 2012) and to provide an in-depth knowledge on a specific phenomenon (Denzin \& Lincoln, 2000; Yin, 2003), especially for business-related empirical studies (Eriksson \& Kovalainen, 2008). A cross-case study sub-method, otherwise known as multiple case analysis, was used to compare and contrast different case studies so that new knowledge can be derived from them (Eisenhardt, 1989; West \& Oldfather, 1995). The details of the methodological process used in this study are presented in the following subsections.

Interview questions, interviewee selection, and procedure Based on the research question of this study, interview questions were developed for each of sectors. The questions had the same structure, which included background, ethical, and research questions. The background questions consisted of academic and professional information, entrepreneurial experience, or company history, and samples of assisted companies. Likewise, the ethical questions were focused on confidentiality and the research questions focused on digitalization and commercialization. All interview questions were open-ended. The selection criteria for interviewees were: 1) an interviewee must be a life sciences stakeholders, 2) they must have more than 10 years' experience in the industry, 3) their present company or institution must be in the industry 4), and their company must operate internationally. The stakeholders, in these criteria, refer to diverse parties who engage in the life sciences industry such as companies, research institutes, and government agents. These criteria were based on recommendations from Prebble and colleagues (2008), Pellika (2014), and Lavoie and colleagues (2017) who suggested that case study participants should represent different stakeholders within the concerned industry. With these criteria, a list of companies was compiled from a region in Finland by contacting pharmaceutical, medical device, and e-health companies, a life sciences park, university technology transfer office (UTTO), and a national organization for innovation funding. Sixteen interviewees participated: four C-level executives (CEOs or CTOs), three business development directors, four top-level staff members of UTTO, four senior business experts, and a director of a funding organization. All these stakeholders were selected because of their roles in the commercialization process and their knowledge about digitalization. The details of these interviewees are presented in Table 1.

The interviews were conducted and recorded at the companies or institutions. The interview sessions to the form of a dialogue because the investigator shared some opinions with the interviewees. Conducting interviews dialogically adds value to collected data (Silverman, 2011).

\section{Data analysis}

A thematic analysis was used because it produces core knowledge of a phenomenon (Braun \& Clarke, 2006; Eriksson \& Kovalainen, 2008). First, three themes were identified according to the research goals and question: 1) digitalization knowledge, 2) commercialization process, and 3) influences of digitalization on the process. Then each theme was analyzed according to the following steps: data familiarization, code generation, theme identification, theme review, themes renaming, and result report (Braun \& Clarke 2006). In following these steps, the recorded interviews were listened to five times and notes were made on each theme according to the interviewees. After that, the interviews were transcribed and were read attentively.

The codes were generated as follows. For theme 1, coding focused on interpretation, level of understanding of digitalization, and examples of digitalization. For theme 


\section{The Effect of Digitalization on the Commercialization Process of High-Technology Companies in the Life Sciences Industry Saheed A. Gbadegeshin}

Table 1. Background information of the interviewees

\begin{tabular}{|c|c|c|c|c|}
\hline & Current Position & Background & Life Sciences Sector & $\begin{array}{l}\text { Type of } \\
\text { Stakeholder }\end{array}$ \\
\hline 1 & $\mathrm{CEO}$ & $\begin{array}{l}\text { A medical doctor and a serial entrepreneur } \\
\text { with more than } 30 \text { years' experience }\end{array}$ & New drug development & Inventor \\
\hline 2 & CEO & A scientist with 20 years' experience & $\begin{array}{l}\text { New drug development } \\
\text { \& Medical device }\end{array}$ & Inventor \\
\hline 3 & CEO & $\begin{array}{l}\text { A scientist and a professional CEO who has } \\
\text { almost } 30 \text { years' experience }\end{array}$ & New drug development & Innovator \\
\hline 4 & CEO & $\begin{array}{l}\text { A physicist and an economist with } 20 \text { years' } \\
\text { experience, mostly as a manager and CEO }\end{array}$ & Medical device & Business developer \\
\hline 5 & $\begin{array}{l}\text { Head of Business } \\
\text { Development }\end{array}$ & $\begin{array}{l}\text { A professional marketer and business } \\
\text { developer who has } 25 \text { years' experience }\end{array}$ & $\begin{array}{l}\text { New drug development } \\
\text { \& Medical device }\end{array}$ & Business developer \\
\hline 6 & $\begin{array}{l}\text { Vice President, } \\
\text { Business Director }\end{array}$ & $\begin{array}{l}\text { A medical doctor and an economist who has } \\
\text { more than } 15 \text { years' experience }\end{array}$ & New drug development & Business developer \\
\hline 7 & $\begin{array}{l}\text { Senior Business } \\
\text { Advisor }\end{array}$ & $\begin{array}{l}\text { A computer scientist who has } 20 \text { years' } \\
\text { experience, mostly working on clinical } \\
\text { instruments and quality assurance for } \\
\text { medical devices }\end{array}$ & E-Health & Business developer \\
\hline 8 & $\begin{array}{l}\text { Senior Business } \\
\text { Advisor }\end{array}$ & $\begin{array}{l}\text { A chemist and an economist with } 40 \text { years' } \\
\text { experience from pharmaceutical and } \\
\text { biotechnology companies }\end{array}$ & All sectors & $\begin{array}{l}\text { Inventor and } \\
\text { Business developer }\end{array}$ \\
\hline 9 & $\begin{array}{l}\text { Senior Business } \\
\text { Advisor }\end{array}$ & $\begin{array}{l}\text { A physicist, a mathematician, and a serial } \\
\text { entrepreneur with } 30 \text { years' experience }\end{array}$ & All sectors & $\begin{array}{l}\text { Innovator and } \\
\text { Business developer }\end{array}$ \\
\hline 10 & $\begin{array}{l}\text { Senior Business } \\
\text { Advisor }\end{array}$ & $\begin{array}{l}\text { A pharmacist and a biochemist with } 30 \\
\text { years' experience }\end{array}$ & $\begin{array}{l}\text { New drug development } \\
\text { \& Medical device }\end{array}$ & Business developer \\
\hline 11 & $\begin{array}{l}\text { Executive Director of } \\
\text { Health and Wellbeing }\end{array}$ & A biotechnologist with 25 years' experience & All sectors & Business developer \\
\hline 12 & $\begin{array}{l}\text { Senior Business } \\
\text { Advisor }\end{array}$ & A biochemist with 40 years' experience & $\begin{array}{l}\text { New drug development } \\
\text { \& Medical device }\end{array}$ & Business developer \\
\hline 13 & $\begin{array}{l}\text { Business Development } \\
\text { Manager }\end{array}$ & $\begin{array}{l}\text { A biochemist and a pharmacologist with } \\
\text { more than } 20 \text { years' experience }\end{array}$ & All sectors & Business developer \\
\hline 14 & Innovation manager & $\begin{array}{l}\text { A chemist and a pharmacologist with more } \\
\text { than } 10 \text { years' experience }\end{array}$ & All sectors & Business developer \\
\hline 15 & Innovation manager & $\begin{array}{l}\text { An economist and a business administrator } \\
\text { with more than } 10 \text { years' experience }\end{array}$ & All sectors & Business developer \\
\hline 16 & Innovation manager & $\begin{array}{l}\text { A biochemist with more than } 10 \text { years' } \\
\text { experience }\end{array}$ & All sectors & Business developer \\
\hline
\end{tabular}




\section{The Effect of Digitalization on the Commercialization Process of High-Technology Companies in the Life Sciences Industry Saheed A. Gbadegeshin}

2, coding focused on stages and activities of the commercialization process of each life sciences sector. And, for theme 3, coding focused on the influences of digitalization on the process for each sector. The generated codes were labelled "indicators" (to avoid confusion with the "themes") and summarized. Then, the indicators were reviewed in relation to the goals and the research question of the article. This review produced "tentative results", which were refined by giving a relevant and intuitive name. An example of the tentative results is presented in Appendix 1. The last step was done by comparing each life sciences sector. Figure 4 details the entire research process.

\section{Findings and Discussion}

\section{Digitization or digitalization?}

It was evident that people interchangeably used "digitization" to mean "digitalization". As Brennen and Kreiss (2016), Degryse (2016), and Parviainen and colleagues (2017) explained, digitalization is the application of information and communication technologies to various spheres of human activity; whereas, digitization is the transformation of analogue pieces of information to digital format. Thus, digitization is a part of digitalization. In the current study, it was found that the participants misused both terms. The examples they offered made it clear that there were using the term digitization to denote digitalization. In fact, their examples revealed that digitalization had penetrated the life sciences industry more than it was previously stated in the work of Bhambure and colleagues (2011). Furthermore, it was noted older CEOs, business experts, university technology transfer officers, and a funding agency director appeared to understand the influences of digitalization on the industry better than younger ones, because they explained differences between before and after the advent of digitalization with clear examples. Their examples include cloud computing, factory automation, expertise management systems, data mining, image processing, video analysis, medical diagnosis, segmentation techniques, biometrics, digital marketing, and virtual organizations.

The above results revealed that there is a need to clarify the difference between the terms, because if the study participants, who are highly educated, could misuse the terms, it might be even more difficult for laypeople to understand the difference between the terms. Therefore, from the examples given by the scholars, the practitioners, and the participants of this study, digitalization is more comprehensive than digitization and it refers to the application of any digital technologies to any human activities, such as personal life, social, economic, and political activities. Meanwhile, digitization is one of the processes of digitalization that converts analogue inputs to digital outputs. Therefore, the difference between the terms is that digitization is a process of the digitalization phenomenon.

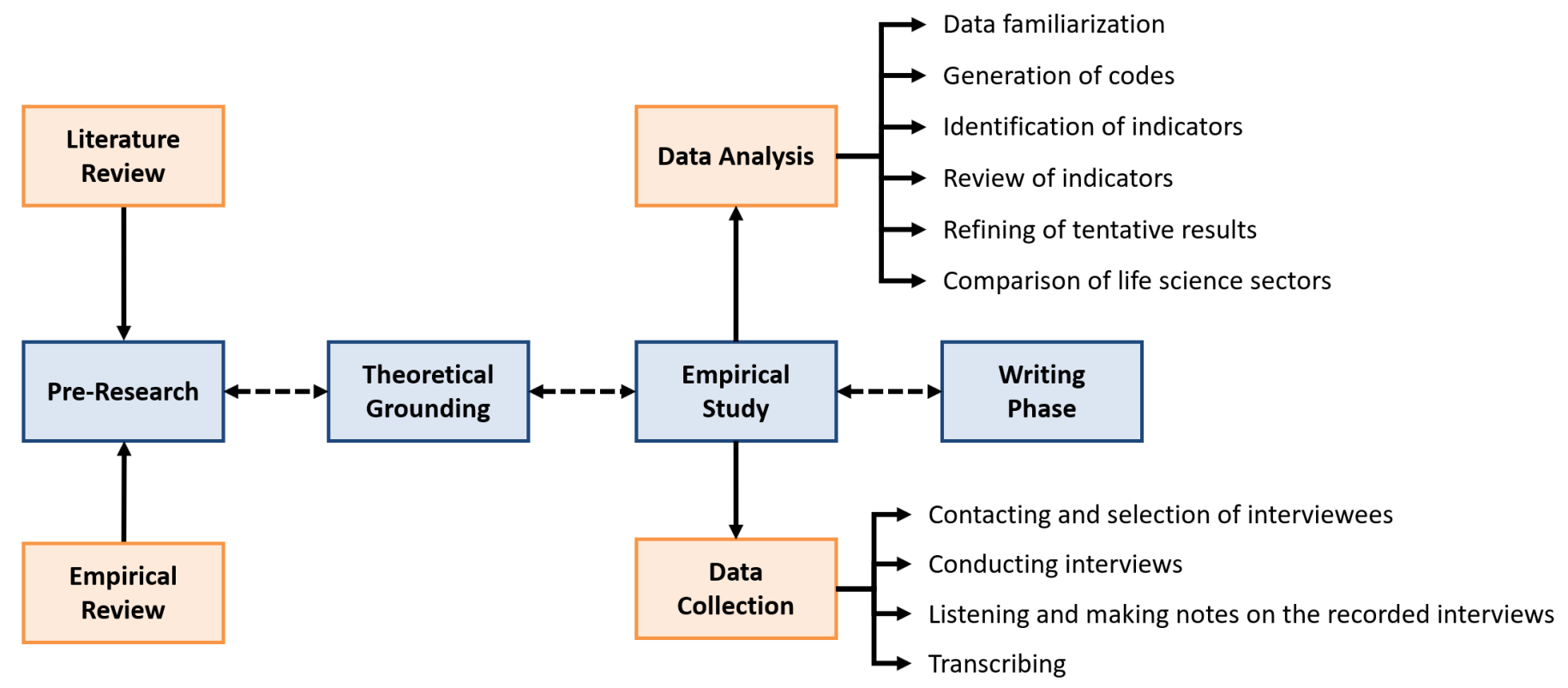

Figure 4. The research process used in this study 


\section{The Effect of Digitalization on the Commercialization Process of High-Technology Companies in the Life Sciences Industry Saheed A. Gbadegeshin}

\section{Digitalization and a new form of commercialization process}

Although pharmaceuticals, medical devices, and ehealth belong to the same industry, they are different in terms of complexity, innovation process, $R \& D$ activities, resource intensity, regulation, and legislation frameworks. Despite their differences, their commercialization processes are changing. All of them seem to have "simultaneous" commercialization process. The traditional stages were there, but the activities of these stages were interconnected. The stages were done in "parallel" or "simultaneously" as observed by Kaitin (2010) and Khilji and co-authors (2006). For example, at the discovery stage, many activities from other phases are undertaken, such as analyses of IP, market, prototyping or production potential, financial, and even, subcontracting. The drivers for a new form of commercialization are cost and timeframe reduction, customer-market orientation, positive entrepreneur attitude, and high need for business. Degryse (2016), Gerlitz (2015), Manyika and colleagues (2013), Markovitch and Willmott (2014), and Parviainen and colleagues (2017) have identified these drivers as motivating factors for adopting digitalization.

The new form of commercialization appears to be different from what the stage-gate theorist, Cooper (2008) explained. The interviewees made it known that, in each stage of commercialization, activities are done according to nature of the discovery. For instance, at the exploration (pharmaceutical) stage, many activities related to discovery and product development and marketization stages are done in addition to the original stage activities. The interviewees also made it known that their parallelization started recently and is enhanced by digitalization, which helps them to execute many commercialization activities simultaneously. This finding corresponds with findings from other researchers (e.g.,
Bhambure et al., 2011; Khilji et al., 2006; McKenzie et al., 2006). Therefore, with digitalization, a new form of commercialization may emerge (Tierney et al. 2013), which focuses on high productivity and quality (McKenzie et al. 2006; Bhambure et al. 2011). This new approach (Kaitin, 2010) does not need to follow the traditional stage-gate model, as shown in Figure 5, which uses the pharmaceutical process as an example.

Figure 5 shows that the commercialization activities are interconnected, and the stages seem to be blurry. Indeed, digitalization clears border lines among different spheres of life, including business operations (Degryse, 2016; Gerlitz, 2015; Parviainen et al., 2017; Schwab, 2015). The figure also shows that commercialization is grouped into three stages: pre-commercialization, actual commercialization, and post-commercialization. This grouping corresponds to the author's earlier works (Gbadegeshin2017b, 2018), which included the observation that "commercialization process does not need to be stage-based or follow the stage-gate process, because simultaneous implementation of commercialization activities seems to facilitate the process as well as manage unexpected problems" (Gbadegeshin (2017b). Although this earlier work focused on a cleantech high technology, it is notable that such a move has also occurred in the more traditional life sciences industry.

Therefore, the arguments stating that commercialization activities should be implemented simultaneously (Al Natsheh et al., 2014; Bradley et al., 2013; Cho et al., 2008; Gbadegeshin, 2017b; Mettlera \& Eurich, 2012; Volpatti \& Yetisen, 2014) seem to be right. The current study affirmed that the simultaneous implementation of commercialization processes is a new form of commercialization process. This new process can be described as a "concurrent commercialization process".

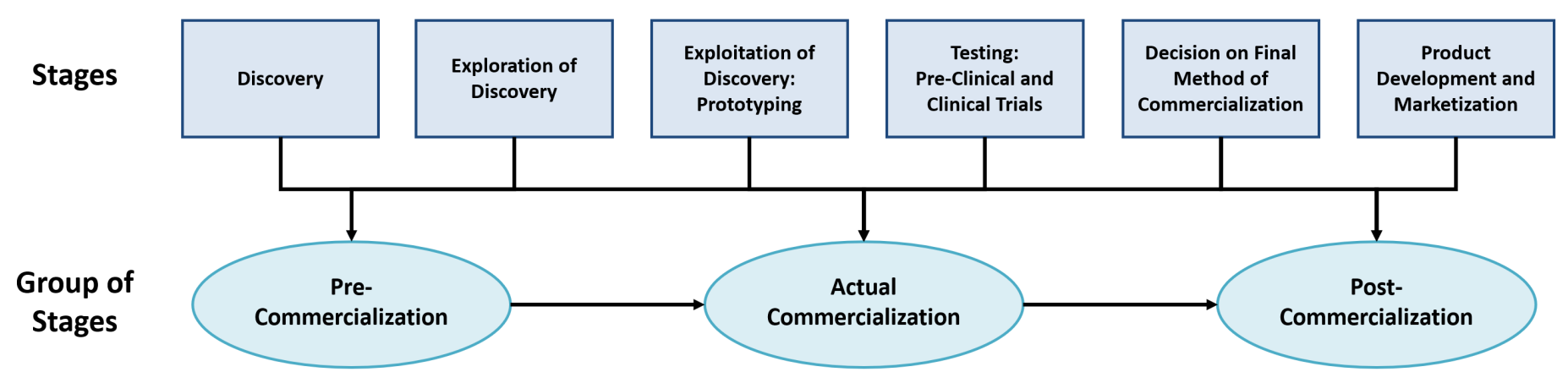

Figure 5. A new commercialization process for pharmaceuticals 


\section{The Effect of Digitalization on the Commercialization Process of High-Technology Companies in the Life Sciences Industry Saheed A. Gbadegeshin}

In addition, this study found that the e-health commercialization framework proposed by Cho and colleagues (2008) needs further improvement. Thus, the current findings suggested that the key stages outlined by these scholars needed to be reframed so that practitioners can understand them. For instance, these scholars proposed "adoption" to mean "conceptualization of innovation"; logically, readers might interpret "adoption" as acceptance of new technology. Similarly, the current findings suggested that the e-health commercialization process is supposed to have five stages, not four: 1) new technology or solution, 2) exploitation of the new technology/solution, 3) decision on commercialization method, 4) protection of the technology/solution, and 5) diffusion and marketization. These new stages could be easily understood by practitioners. In the new stages, commercialization activities are similar to the above medical and pharmaceutical companies, which align them with the life sciences industry. Furthermore, stage 4 (protection of the technology/solution) is the main difference between the previous framework of Cho and colleagues (2008) and the new framework. This stage is essential because there is a need to protect intellectual property due to the effect of digitalization, which makes much more information available and accessible online. In a nutshell, an improved form of ehealth commercialization process is shown in Figure 6.

The interviewees also disclosed that there is much information available online these days on every aspect of commercialization and that digitalization enables them to reach the state-of-the-art of any discovery (technology or solution). It also enables them to monitor, observe, and sometimes predict incoming products and solutions. This accessibility assists them in making market-entry decisions. All these possibilities were nowhere to be found a few decades ago. Hence, digitalization influenced the way commercialization informa- tion is planned, organized, coordinated, and controlled. For instance, a commercialization team may be spread across the globe because of outsourcing, and sensitive information needs careful attention, such information is now stored and shared in secured platforms. Sensitive information now can be checked and coordinated online. The interviewees recalled that previous forms of information management were tedious and cumbersome. Meanwhile, with digitalization, managing information is easier and less expensive, but riskier. This finding adds value to existing studies showing that digitalization influences innovation processes in the life sciences industry (Bhambure et al., 2011; Kaitin, 2010; McKenzie et al., 2006) by showing that digitalization's influence is not only on the innovation process; it also affects the commercialization process.

Furthermore, the interviewees revealed that they employed different types of digitalization tools, such as AI and big data analytics, to evaluate scholarly discussions (via articles), and to derive information on different scientific methods or techniques, possible trends, and sometimes, forthcoming drugs or technologies or solutions. An example was given by one of the interviewees stating that he knows the number of new drugs that will be available in the market from this year (2018) up to 2028. The interviewee claimed that he and his team were able to know this through their science and marketing assessments. He also explained that their predictions have been right since the beginning of 2014. They were able to do this with the help of digitalization. The interviewee recalled that this "intelligence" information could never have been attained 20 years ago without vast financial resources. This result relates to the work of Sabbagh and colleagues (2012) and Quinton and Simkin (2016), who argued that digitalization enables companies to monitor their competition. Meanwhile, this finding is relevant beyond competition management; it

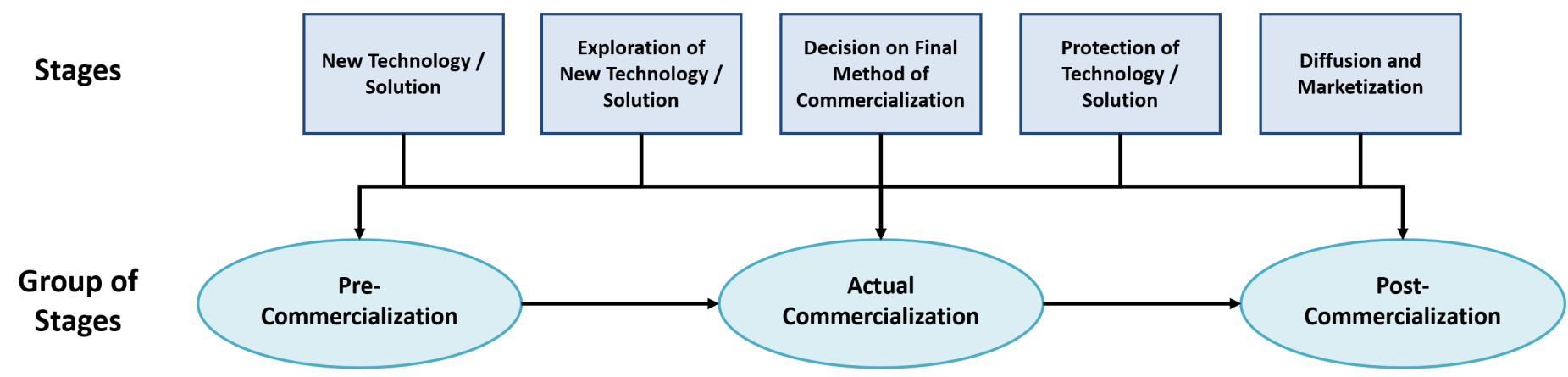

Figure 6. A new commercialization process for e-health 


\section{The Effect of Digitalization on the Commercialization Process of High-Technology Companies in the Life Sciences Industry Saheed A. Gbadegeshin}

shows that digitalization can be used to evaluate different issues in the commercialization process and gain insight for better decision making.

The data also showed that many official processes are now digitized. The paper forms are now available online, bills are paid online, questions are answered online (mostly through email interaction and online feedback), application monitoring is done online, and even, booking for face-to-face meetings is done online. Unlike previous works, which acknowledge that digitization is a part of digitalization transformation (e.g., Degryse, 2016; Parviainen et al., 2017; Tihinen \& Kääriäinen, 2016), this finding affirmed that the transformation is almost completed and is influencing official processes and activities.

The participants also affirmed that their commercialization activities have led to the creation of millions of pieces of information. For instance, they created new big data from information sourcing and management, using AI for big data analysis, prototyping and testing (including clinical trials), conducting marketing intelligence, using robots for mass production, and collaborating. The issue of creating more data from utilizing new data is not yet discussed by scholars in the digitalization field, such as Manyika and colleagues (2013), and Degryse (2016), and Tihinen and Kääriäinen (2016). Therefore, this finding is new and may need further attention by scholars.

One of the advantages of digitalization is efficiency and effectiveness (Manyika et al., 2013; Markovitch \& Willmott, 2014; Parviainen et al., 2017). However, the participants made it known that the application of digitalization tools adds more to their workload as well as makes the new activities become routine. For example, conducting potential partner analyses are now becoming daily activities for a commercialization project team. It is somewhat counterintuitive that digitalization may add to the workload, therefore further investigation about this possible negative influence of digitalization is needed.

Finally, the interviewees explained that digitalization made their commercialization flexible, effective, and efficient, which corresponds with earlier studies (e.g., Bhambure et al., 2011; McKenzie et al., 2006). However, the interviewees noted security issues (e.g., the risk of cyber-attacks), insufficient/incorrect information, exposure to business predators, and limitations on secrecy. The study participants also showed concerns about high dependence on the Internet and digitaliza- tion. Thus, despite the benefits of digitalization, it is also the source of new risks and associated "digital fear".

\section{Conclusion}

Scholars, politicians, and business leaders have all recognized that digitalization affects every aspect of human activities, both positively and negatively (Degryse, 2016; The Economist, 2012; Parviainen et al., 2017; Schwab, 2015; Tihinen \& Kääriäinen, 2016; World Economic Forum, 2018). The current study supports this view by highlighting the impact of digitalization on the commercialization processes of the life sciences industry - an industry where the effects on human activities can be profound.

The effect of digitalization leads to a new form of commercialization process. If this effect continues, it can be argued that the commercialization process will become more iterative, lean, or agile because commercialization activities will be more flexible and intertwined, as Schwab (2015) and Gerlitz (2015) have stated. Additionally, an iterative and lean process will be needed for the discovery and commercialization of new technologies. Thus, an iterative and lean process paves the way for rapid commercialization (Gbadegeshin 2017a, 2018; Gbadegeshin \& Heinonen, 2016) by shortening the duration of the process, which is essential for the current high demand for commercialization of innovations or inventions (Still, 2017). Furthermore, if the influences of digitalization on official processes, big data, workloads, and digital fears continued, as Tihinen and Kääriäinen (2016) and Parviainen and colleagues (2017) noted, these influences would change the business models of the life sciences industry and soften government regulations. Therefore, it can be concluded that digitalization has both positive and negative influences on the commercialization process.

This article makes a theoretical contribution to the study of digitalization by showing how it influences commercialization processes. It also makes a theoretical contribution by revealing a new form of commercialization process, which has not yet been discussed by commercialization scholars and practitioners. Additionally, it contributes to the theoretical discussion of digitalization by revealing that digitalization influenced workload, government procedures, big data, and digital fear, which have not yet been investigated by digitalization scholars and experts. Furthermore, the article contributes to practice by identifying the areas that digitalization has influenced. These contributions are relevant to academics, practitioners, and policy makers 


\section{The Effect of Digitalization on the Commercialization Process of High-Technology Companies in the Life Sciences Industry Saheed A. Gbadegeshin}

and call for more open discussions on the impacts of the digitalization - not only on the commercialization process, but also on the other aspects of human activities.

Besides the contributions, the article has limitations. The first limitation comes from the research methodology the study employed. Normally, the case study method offers limited generalization (Denzin \& Lincoln 2000; Eriksson \& Kovalainen 2008; Yin 2003). Thus, the findings derived from a few sectors of an industry might not be generalized. Similarly, a case study drawn from a single region of a small populated country (Finland) calls for caution in generalizing the results. Another limitation is the focus of the study, which concentrates only on the application of digitalization to the commercialization process.

However, these limitations suggest research opportunities for future studies. For instance, the findings of the article could serve as variables that can be tested quantitatively among the life science sectors in any country or between countries. Additionally, there is a need for further research on the new form of commercialization process and its methodology in the industry and other industries. This kind of research will shed more light on the changes that emerge from different forms of digitalization. There is also a need for studies on the future impact of digitalization on commercialization. Finally, there is a need for research on how digitalization has affected different business activities, such as business model development and the acquisition of new skills (especially, commercialization skills: see Gbadegeshin, 2019). Such research will provide insights on human resource management for universities, governments, and industries.

\section{Acknowledgements}

The author would like to thank the Finnish Cultural Foundation, the Foundation for Economic Education, the Turku University Foundation, TOP-Säätiö, and Turku School of Economics Support Foundation (Matti Koivurinnansäätiö) for their financial support. The author also thanks his supervisors: Professor Jarna Heinonen and Professor Anne Kovalainen, as well as his colleagues, especially Dr Solomon Oyelere, Dr Luqman Awoniyi, Dr Sunday Olaleye, Dr Tunde Jogunola, and Mr Ezak Ofem, for their feedback on the manuscript drafts.

\section{About the Author}

Saheed A. Gbadegeshin is a PhD Candidate at Turku School of Economics, University of Turku, Finland. His research interests include commercialization, high technology, the lean startup methodology, entrepreneurship, business internationalization, and family-run businesses. He holds an MSc degree in Entrepreneurship from the University of Jyväskylä and an MBA in International Business Management from Turku University of Applied Sciences in Finland.

\section{References}

Abd Rahim, N., Mohamed, Z. B., \& Amrin, A. 2015. Commercialization of Emerging Technology: The Role of Academic Entrepreneur. Procedia - Social and Behavioral Sciences, 169: 53-60. http://doi.org/10.1016/j.sbspro.2015.01.285

Al Natsheh, A., Gbadegeshin, S. A., Rimpiläinen, A., \& Mainela, T. 2013. Technology Based Entrepreneurship: Measurement Technology Perspective. Interdisciplinary Journal of Research in Business, 2(9): $26-42$.

Al Natsheh, A., Gbadegeshin, S. A., Rimpiläinen, A., Imamovic-Tokalic, I., \& Zambrano, A. 2014. Building a Sustainable Start-up? Factors to Be Considered During the Technology Commercialization Process. Journal of Advanced Research in Entrepreneurship and New Venture Creation, 1(1): 4-19.

Bhambure, R., Kumar, K., \& Rathore, A. S. 2011. High-Throughput Process Development for Biopharmaceutical Drug Substances. Trends in Biotechnology, 29(3): 127-135. http://doi.org/10.1016/j.tibtech.2010.12.001

Bradley, S. R., Hayter, C. S., \& Link, A. N. 2013. Models and Methods of University Technology Transfer. Foundations and Trends in Entrepreneurship, 9(6): 571-650. http://dx.doi.org/10.1561/0300000048

Braun, V., \& Clarke, V. 2006. Using Thematic Analysis in Psychology. Qualitative Research in Psychology, 3(2): 77-101. https://doi.org/10.1191/1478088706qp063oa

Brennen, S. J., \& Kreiss, D. 2016. Digitalization and Digitization. In K. Bruhn Jensen, R. T. Craig, J. D. Pooley, \& E. W. Rothenbuhler (Eds.), The International Encyclopedia of Communication Theory and Philosophy. Oxford, UK: Wiley-Blackwell. https://doi.org/10.1002/9781118766804.wbiect111

Cho, S., Mathiassen, L., \& Gallivan, M. 2008. Cross the Chasm: From Adoption to Diffusion of a Telehealth Innovation. In G. León, A. Bernardos, J. Casar, K. Kautz, \& J. DeGross, (Eds), International Federation for Information Processing: Open IT-Based Innovation: Moving Towards Cooperative IT Transfer and Knowledge Diffusion: 361-378. Boston, MA: Springer.

https://doi.org/10.1007/978-0-387-87503-3_21

Cooper, R. G. 2008. The Stage-Gate- Idea-to-Launch Process-Update: What's New and NextGen Systems. Journal of Product Innovation Management, 25(3): 213-232.

https://doi.org/10.1111/j.1540-5885.2008.00296.x 


\section{The Effect of Digitalization on the Commercialization Process of High-Technology Companies in the Life Sciences Industry Saheed A. Gbadegeshin}

Degryse, C. 2016. Digitalisation of the Economy and Its Impact on Labour Markets. Working Paper 2016.02. Brussels: European Trade Union Institute (ETUI).

Denzin, N. K., \& Lincoln, Y. S. (Eds). 2000. Handbook of Qualitative Research (2nd ed.). Thousand Oaks, CA: Sage Publication Inc.

Dogra, R., Garg, R., \& Jatav, P. 2013. Technology Transfer in Pharmaceutical Industry: Transfer of Process from Development to Commercialization. International Journal of Pharmaceutical Sciences and Research, 4(5): 1692-1708.

http://dx.doi.org/10.13040/IJPSR.0975-8232.4(5).1692-08

Eriksson, P., \& Kovalainen, A. 2008. Qualitative Methods in Business Research. London: Sage Publications Ltd. http://dx.doi.org/10.4135/9780857028044

Eisenhardt, K. M. 1989. Building Theories from Case Study Research. Academy of Management Review, 14(4): 532-550. http://dx.doi.org/10.2307/258557

European Commission. 2009. Pharmaceutical Sector Inquiry: Final Report. Brussels: European Commission.

http://ec.europa.eu/competition/sectors/pharmaceuticals/inquir y/staff_working_paper_part1.pdf

Eurostat. 2016. High-Technology Versus Low-Technology Manufacturing. Eurostat: Statistics Explained, April 13, 2016. Accessed January 15, 2019:

https://ec.europa.eu/eurostat/statisticsexplained/index.php?title=Archive:High-technology_versus_lowtechnology_manufacturing

Fontes, F. 2005. The Process of Transformation of Scientific and Technological Knowledge into Economic Value Conducted by Biotechnology Spin-offs. Technovation, 25(4): 339-347. https://doi.org/10.1016/j.technovation.2003.08.004

Gaubinger, K., Schweitzer, F., \& Zweimüller, R. 2012. A Commercialization Process Model for Technology Innovations. Paper presented at the 2012 International Society for Professional Innovation Management (ISPIM) Conference, June 17-20, 2012, Barcelona, Spain.

Gbadegeshin, S. A. 2017a. Stating Best Commercialization Method: An Unanswered Question from Scholars and Practitioners. International Journal of Social, Behavioral, Educational, Economic, Business and Industrial Engineering, 11(5): 1088-1094.

Gbadegeshin, S. A. 2017b. Commercialization Process of High Technologies: Case Study of Finnish University Spin-off. Academy of Entrepreneurship Journal, 23(2): 1-22.

Gbadegeshin, S. A. 2018. Lean Commercialization: A Framework for Commercializing High Technologies. Technology Innovation Management Review, 8(9): 50-63.

http://doi.org/10.22215/timreview/1186

Gbadegeshin, S. A. 2019. Commercialization Skills: Necessity for High Technology Entrepreneurs in Digital Era. In K. Arai, R. Bhatia, \& S. Kapoor (Eds), Proceedings of the Future Technologies Conference (FTC) 2018: Advances in Intelligent Systems and Computing: 965-975. Cham, Switzerland: Springer.

https://doi.org/10.1007/978-3-030-02683-7_71

Gbadegeshin, S. A., \& Heinonen, L. 2016. Application of the Lean Start-Up Technique in Commercialisation of Business Ideas and Innovations. International Journal of Business Management and Research, 43(1): 1270-1285.
Gerlitz, L. 2015. Design for Product and Service Innovation in Industry 4.0 in Emerging Smart Society. Journal of Security and Sustainability Issues, 5(2): 181-198.

https://doi.org/10.9770/jssi.2015.5.2(5)

Henriette, E., Feki, M., \& Boughzala, I. 2015. The Shape of Digital Transformation: A Systematic Literature Review. In S. Kokolakis, M. Karyda, E. N. Loukis, \& Y. Charalabidis. (Eds.), Proceedings from Ninth Mediterranean Conference on Information Systems (MCIS), Samos, Greece: 431-443.

Holzleitner, R. 2015. A Comprehensive Framework for Successful Commercialisation of Technology Push Innovations. Paper presented at the 2015 International Society for Professional Innovation Management (ISPIM) Special Workshop, Upper Austria University of Applied Sciences.

http://ffhoarep.fh-ooe.at/bitstream/123456789/430/1/FFH2015IM2-4.pdf

Istepanaian, R. S. H., \& Zhang, Y.-T. 2012. Guest Editorial Introduction to the Special Section: 4G Health: The Long-Term Evolution of m-Health. IEEE Transactions on Information Technology in Biomedicine, 16(1): 1-5. https://doi.org/10.1109/TITB.2012.2183269

Kaitin, K. I. 2010. Deconstructing the Drug Development Process: The New Face of Innovation. Clinical Pharmacology \& Therapeutics, 87(3): 356-361. https://doi.org/10.1038/clpt.2009.293

Khilji, S. E., Mroczkowski, T., \& Bernstein, B. 2006. From Invention to Innovation: Toward Developing an Integrated Innovation Model for Biotech Firms. Journal of Product Innovation Management, 23(6): 528-540. https://doi.org/10.1111/j.1540-5885.2006.00222.x

Kumar, S., Nilsen, W. J., Abernethy, A., Atienza, A., Patrick, K., Pavel, M., Riley, W. T., Shar, A., Spring, B., Spruijt-Metz, D., Hedeker, D., Honavar, V., Kravitz, R., Lefebvre, R. C., Mohr, D. C., Murphy, S. A., Quinn, C., Shusterman, V., \& Swendeman, D. 2013. Mobile Health Technology Evaluation: The mHealth Evidence Workshop. American Journal of Preventive Medicine, 45(2): 228-236. https://doi.org/10.1016/j.amepre.2013.03.017

Lavoie, J. R., Kim, J., \& Daim, T. U. 2017. A Technology Transfer Framework: A Case Study from the Energy Sector. International Journal of Innovation, Management and Technology, 8(4): 249-260. https://doi.org/10.18178/ijimt.2017.8.4.737

Maak, T. G., \& Wylie, J. D. 2016. Medical Device Regulation: A Comparison of the United States and the European Union. Journal of the American Academy of Orthopaedic Surgeons, 24(8): 537-543. https://doi.org/10.5435/JAAOS-D-15-00403

Maine, E., \& Garnsey, E. 2007. The Commercialisation Environment of Advanced Materials Ventures. International Journal of Technology Management, 39(1/2): 49-71. https://doi.org/10.1504/IJTM.2007.013440

Manyika, J., Chui, M., Bughin, J., Dobbs, R., Bisson, P., \& Marrs, A. 2013. Disruptive Technologies: Advances that Will Transform Life, Business, and the Global Economy. Washington, DC: McKinsey Global Institute.

Markovitch, S., \& Willmott, P. 2014. Accelerating the Digitization of Business Processes. Digital McKinsey, May 2014. Accessed January 15, 2019:

http://www.mckinsey.com/business-functions/digitalmckinsey/our-insights/accelerating-the-digitization-of-businessprocesses 


\section{The Effect of Digitalization on the Commercialization Process of High-Technology Companies in the Life Sciences Industry Saheed A. Gbadegeshin}

McKenzie, P., Kiang, S., Tom, J., Rubin, A. E., \& Futran, M. 2006. Can Pharmaceutical Process Development Become High Tech? AIChE Journal, 52(12): 3990-3994.

https://doi.org/10.1002/aic.11022

Mettlera, T., \& Eurich, M. 2012. A “Design-Pattern”-Based Approach for Analyzing E-health Business Models. Health Policy and Technology, 1(2): 77-85.

https://doi.org/10.1016/j.hlpt.2012.04.005

Meyers, A. D. 2009. Book Review: Commercialisation of Innovative Technologies: Bringing Good Ideas to the Marketplace. Journal of Commercial Biotechnology, 15(4): 374-375.

https://doi.org/10.1057/jcb.2009.18

Nilsson, A., Friden, H., \& Serger, S. S. 2006. Commercialisation of Life Sciences Research at Universities in the United States, Japan, and China. Study A2006:006. Östersund, Sweden: Swedish Institute for Growth Policy Studies.

Nissen, H. A., Evald, M. R., \& Clarke, A. H. 2015. Firms' Reshaping of Commercialization Practices to Overcome the 'Not Invented Here' Phenomenon in Public Health Care Organizations. The Innovation Journal: The Public Sector Innovation Journal, 20(3): 1-27.

Parviainen, P., Tihinen, M., Kääriäinen, J., \& Teppola, S. 2017. Tackling the Digitalization Challenge: How to Benefit from Digitalization in Practice. International Journal of Information Systems and Project Management, 5(1): 63-77. https://doi.org/10.12821/ijispm050104

Pellika, J. 2014. The Commercialization Process of Innovation in Small High-Technological Firms - Theoretical View. In F. Thérin (Ed.), Handbook of Research on Techno-Entrepreneurship: How Technology and Entrepreneurship Are Shaping the Development of Industries and Companies (2nd ed.): 91-109. Cheltenham, UK: Edward Elgar Publishing Ltd.

Pellikka, J., \& Malinen, P. 2011. Developing Commercialisation of Innovation in High Technology Industries - Regional Perspective. Paper presented at the 56th International Council for Small Business (ICSB) in Stockholm, Sweden, June 15-18, 2011.

Pietzsch, J. B., Shluzas, L. A., Paté-Cornell, M. E., Yock, P. G., \& Linehan, J. H. 2009. Stage-Gate Process for the Development of Medical Devices. Journal of Medical Devices, 3(2): 021004. https://doi.org/10.1115/1.3148836

Prebble, D. R., De Waal, G. A., \& De Groot, C. 2008. Applying Multiple Perspectives to the Design of a Commercialization process. $R \& D$ Management, 38(3): 311-320.

https://doi.org/10.1111/j.1467-9310.2008.00517.x

Quinton, S., \& Simkin, L. 2016. The Digital Journey: Reflected Learnings and Emerging Challenges. International Journal of Management Reviews, 19(4): 455-472. https://doi.org/10.1111/ijmr.12104

Sabbagh, K., Friedrich, R., El-Darwiche, B., Singh, M., Ganediwalla, S., \& Katz, R. 2012. Maximizing the Impact of Digitization. New York: Booz \& Company.

http://www.strategyand.pwc.com/media/file/Strategyand_Maxim izing-the-Impact-of-Digitization.pdf

Schwab, K. 2015. The Fourth Industrial Revolution: What It Means and How to Respond. Foreign Affairs, December 12, 2015. Accessed January 15, 2019:

https://www.foreignaffairs.com/articles/2015-12-12/fourthindustrial-revolution
Siegel, D. S., Waldman, D. A., Atwater, L. E., \& Link, A. N. 2004. Toward a Model of the Effective Transfer of Scientific Knowledge from Academicians to Practitioners: Qualitative Evidence from the Commercialization of University Technologies. Journal of Engineering and Technology Management, 21(1-2): 115-142. https://doi.org/10.1016/j.jengtecman.2003.12.006

Silverman, D. 2011. Interpreting Qualitative Data: A Guide to the Principles of Qualitative Research (4th ed). London: Sage Publications Ltd.

Speser, P. 2008. What Every Researcher Needs to Know About Commercialisation. Providence, RI: Foresight Science and Technology Inc.

Soenksen, L. R., \& Yazdi, Y. 2017. Stage-Gate Process for Life Sciences and Medical Innovation Investment. Technovation, 62-63: 14-21. https://doi.org/10.1016/j.technovation.2017.03.003

Solberg, C. A., Sundal, T., \& Thoresen, K. 2008. High-Tech and LowTech Born Globals: Are They Any Different? Paper presented at Annual EIBA conference in Tallinn, Estonia, December 2008.

Steenhuis, H. J., \& de Bruijn, E. J. 2006. High Technology Revisited: Definition and Position. In Proceedings of IEEE International Conference on Management of Innovation and Technology: 1080-1084. Singapore, June 21-23, 2006.

https://doi.org/10.1109/ICMIT.2006.262389

Sternitzke, C. 2010. Knowledge Sources, Patent Protection, and Commercialization of Pharmaceutical Innovations. Research Policy, 39(6): 810-821. https://doi.org/10.1016/j.respol.2010.03.001

Still, K. 2017. Accelerating Research Innovation by Adopting the Lean Startup Paradigm. Technology Innovation Management Review, 7(5): 32-43. http://doi.org/10.22215/timreview/1075

The Economist. 2012. The Third Industrial Revolution: The Digitisation of Manufacturing Will Transform the Way Goods Are Made and Change the Politics of Jobs Too. The Economist, April 21, 2012. Accessed January 15, 2019:

http://www.economist.com/node/21553017

Tierney, R., Hermin, W., \& Walsh, S. 2013. The Pharmaceutical Technology Landscape: A New Form of Technology Road Mapping. Technological Forecasting \& Social Change, 80(2): 194-211.

https://doi.org/10.1016/j.techfore.2012.05.002

Tihinen, M., \& Kääriäinen, J. (Eds.) 2016. The Industrial Internet in Finland: on Route to Success? Espoo, Finland: VTT Technology. http://www.vtt.fi/inf/pdf/technology/2016/T278.pdf

Volpatti, L. R., \& Yetisen, A. K. 2014. Commercialisation of Microfluidic Devices. Trends in Biotechnology, 32(7): 347-350. https://doi.org/10.1016/j.tibtech.2014.04.010

Walsh, P. R. 2012. Innovation Nirvana or Innovation Wasteland? Identifying Commercialization Strategies for Small and Medium Renewable Energy Enterprises. Technovation, 32(1): 32-42. https://doi.org/10.1016/j.technovation.2011.09.002

West, J., \& Oldfather, P. 1995. Pooled Case Comparison: An Innovation for Cross-Case Study. Qualitative Inquiry, 1(4): $452-464$.

https://doi.org/10.1177/107780049500100405 


\section{The Effect of Digitalization on the Commercialization Process of High-Technology Companies in the Life Sciences Industry Saheed A. Gbadegeshin}

World Economic Forum. 2018. Jack Ma on the IQ of Love and Other Top Quotes from his Davos Interview. World Economic Forum, January 24, 2018. Accessed January 15, 2019:

https://www.weforum.org/agenda/2018/01/jack-ma-davos-topquotes/
World Health Organization. 2003. eHealth. Geneva, Switzerland: World Health Organization.

http://www.emro.who.int/ehealth/

Yin, R. K. 2003. Case Study Research: Design and Methods (2nd ed). New York: Sage Publications Inc.

Appendix 1. Tentative results on the influences of digitalization on the commercialization process

\begin{tabular}{|c|c|c|}
\hline Pharmaceutical Sector & Medical Device Sector & E-Health Sector \\
\hline $\begin{array}{l}\text { Discovery } \\
\text { - Accessing scholarly articles (easily) } \\
\text { - Monitoring science focus (easily) } \\
\text { - Evaluating novelty } \\
\text { - Accessing new method/technique } \\
\text { - Deducing new } \\
\text { molecule/knowledge/novelty } \\
\text { - Identifying new problem or trend in } \\
\text { existing problem } \\
\text { - Defining market needs }\end{array}$ & $\begin{array}{l}\text { Discovery (New technology) } \\
\text { - Accessing scholarly articles (easily) } \\
\text { - Deducing new technology/knowledge } \\
\text { - Identifying new problem or trend in } \\
\text { existing problem } \\
\text { - Defining market needs }\end{array}$ & $\begin{array}{l}\text { Discovery (New application or solution) } \\
\text { - Accessing all available solutions and their } \\
\text { weaknesses } \\
\text { - Defining novelty (uniqueness) } \\
\text { - Planning for development of the } \\
\text { application or solution } \\
\text { - Accessing solution delivery mode } \\
\text { - Evaluating market needs } \\
\text { - Evaluating possible legal constraints } \\
\text { - Monitoring problem trends or market } \\
\text { - Arend } \\
\text { - Evsessing technical possibilities }\end{array}$ \\
\hline $\begin{array}{l}\text { Exploration of discovery } \\
\text { - Assessing technical possibilities } \\
\text { - Evaluating IP situations } \\
\text { - Screening molecules before starting any } \\
\text { large investment } \\
\text { - Developing alternative molecules } \\
\text { - Detecting similar and previous failures } \\
\text { - Analyzing business potential } \\
\text { - Compiling knowledge on forthcoming } \\
\text { - (similar) drugs } \\
\text { - Analyzing potential competitors } \\
\text { - Enabling own company profiling } \\
\text { - Developing qualitative business case } \\
\text { - Evaluating potential collaborators and } \\
\text { - Recruiting personnel, partners, and } \\
\text { collaborators } \\
\text { - Digitization (changing paper documents } \\
\text { to digital form) }\end{array}$ & $\begin{array}{l}\text { Assessment of discovery } \\
\text { - Evaluating novelty } \\
\text { - Analyzing IP } \\
\text { - Assessing technical development } \\
\text { possibilities } \\
\text { - Assessing business potential (mostly } \\
\quad \text { conducting market analysis) }\end{array}$ & $\begin{array}{l}\text { Exploitation of new application/solution } \\
\text { - Prototyping } \\
\text { - Normal testing } \\
\text { - Clinical testing }\end{array}$ \\
\hline $\begin{array}{l}\text { Exploitation of discovery } \\
\text { - Assessing and contacting potential } \\
\text { financiers, partners, and collaborators } \\
\text { (communication purpose) } \\
\text { - Managing drug process (e.g., outsourcing, } \\
\text { maintaining information sharing } \\
\text { platform, enabling iteration process) } \\
\text { - Enabling use of modern technologies } \\
\text { (e.g., use of silicon material) }\end{array}$ & $\begin{array}{l}\text { Protection of discovery } \\
\text { - Facilitating patent filing (digitization) } \\
\text { - Facilitating of "CE" certificate registration }\end{array}$ & $\begin{array}{l}\text { Decision on final method of } \\
\text { commercialization } \\
\text { - Analyzing market information } \\
\text { - Assessing new solution market value } \\
\text { - Assessing different methods and their } \\
\text { potential outcomes }\end{array}$ \\
\hline
\end{tabular}




\section{The Effect of Digitalization on the Commercialization Process of High-Technology Companies in the Life Sciences Industry Saheed A. Gbadegeshin}

\section{Appendix 1 (continued). Tentative results on the influences of digitalization on the commercialization process}

\begin{tabular}{|c|c|c|}
\hline Pharmaceutical Sector & Medical Device Sector & E-Health Sector \\
\hline $\begin{array}{l}\text { Testing: pre-clinical and clinical trials } \\
\text { - Maintaining relationship with the } \\
\text { financiers, partners, and collaborators } \\
\text { (communication purpose) } \\
\text { - Managing the drug process } \\
\text { - Collecting information on previous trials } \\
\text { - Producing prototype (easily) (selecting } \\
\text { promising candidates) } \\
\text { - Recruiting of patients } \\
\text { - Easy trial data collection and analysis } \\
\text { - Easy trial monitoring and management } \\
\text { - Reducing cost (more than before arrival } \\
\text { of digitalization) }\end{array}$ & $\begin{array}{l}\text { Prototyping, development, and testing } \\
\text { - Assessing and contacting potential } \\
\text { partners and collaborators } \\
\text { - Analyzing potential competitors } \\
\text { - Easy production of prototype (e.g., with } \\
\text { 3D printer and outsourcing) } \\
\text { - Recruiting personnel, partners, and } \\
\text { collaborators } \\
\text { - Easy conduction of preclinical and } \\
\text { clinical tests }\end{array}$ & $\begin{array}{l}\text { Protection of new application/solution } \\
\text { - Facilitating patent filing (digitization) }\end{array}$ \\
\hline $\begin{array}{l}\text { Decision on final method of } \\
\text { commercialization } \\
\text { - Analyzing market information } \\
\text { - Assessing new drug market value } \\
\text { - Assessing different methods and their } \\
\text { potential outcomes } \\
\text { - Evaluating potential licensees or IP } \\
\text { buyers }\end{array}$ & $\begin{array}{l}\text { Decision on final method of } \\
\text { commercialization } \\
\text { - Analyzing market information } \\
\text { - Assessing new device market value } \\
\text { - Assessing different methods and their } \\
\text { potential outcomes } \\
\text { - Evaluating potential licensees or IP } \\
\text { buyers } \\
\text { - Evaluating own production process }\end{array}$ & $\begin{array}{l}\text { Diffusion and marketization } \\
\text { - Reviewing production process } \\
\text { - Using of many marketing tools with lesser } \\
\text { cost } \\
\text { - Easy management of post-sales activities } \\
\text { (e.g., feedback) } \\
\text { - Creation of new big data }\end{array}$ \\
\hline
\end{tabular}

\section{Product development and marketization}

- Reviewing new drug production process

- Evaluating subcontractors

- Planning manufacturing process

- Using of robots, virtual reality, and augmented reality (for production process and management purposes)

- Promoting personalized medicine (different use of dosage)

- Changing workforce composition

- Using various marketing tools at lower cost

- Easy management of post-sales activities (e.g., feedback)

- Creation of new big data

\section{Product development and marketization}

- Reviewing production process

- Evaluating subcontractors

- Planning manufacturing process (e.g., using robots)

- Changing workforce composition

- Using of many marketing tools with lesser cost

- Easy management of post-sales activities (e.g., feedback)

- Creation of new big data 


\section{Academic Affiliations and Funding Acknowledgements}
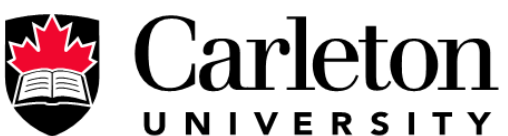

U N I V E R S I T Y

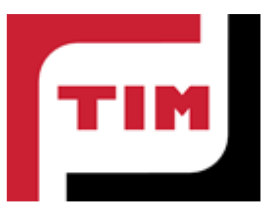

Technology Innovation Management (TIM; timprogram.ca) is an international master's level program at Carleton University in Ottawa, Canada. It leads to a Master of Applied Science (M.A.Sc.) degree, a Master of Engineering (M.Eng.) degree, or a Master of Entrepreneurship (M.Ent.) degree. The objective of this program is to train aspiring entrepreneurs on creating wealth at the early stages of company or opportunity lifecycles.

- The TIM Review is published in association with and receives partial funding from the TIM program. 